\title{
Evaluation of Changes in Gastric Ph and Gastrine Concentrations in Horses Subjected to Inhalatory General Anesthesia in Dorsal Decubitus
}

Jesus Leonardo Suarez Guerrero

University of São Paulo (USP)

Pedro Henrique Salles Brito

University of São Paulo (USP)

Marilia Alves Ferreira

University of São Paulo (USP)

Julia de Asis Arantes

University of São Paulo (USP)

Elidiane Rush

University of São Paulo (USP)

Adriano Bonfim Carregaro

University of São Paulo (USP)

Renata Gebara Sampaio Doria ( $\nabla$ redoria@usp.br)

University of São Paulo (USP)

\section{Research Article}

Keywords: anesthesia, decubitus, entero-gastric, gastrin, gastroenterology, horses, reflux

Posted Date: November 30th, 2021

DOI: https://doi.org/10.21203/rs.3.rs-1051477/v1

License: (c) (1) This work is licensed under a Creative Commons Attribution 4.0 International License. Read Full License 


\section{Abstract}

Background: In high-performance horses, it is reported that 50 to $90 \%$ have stomach disorders, especially gastritis and gastric ulceration, which compromises both, athletic performances, and health status. This work aims to stablish changes in gastric $\mathrm{pH}$ and gastrin hormone in horses submitted to general inhalation anesthesia and in supine position, to determine the occurrence of duodenogastric and gastroesophageal reflux. Eight mares fasted for eight hours, subjected to inhaled anesthesia and in supine position were monitored during the anesthetic period. Gastric $\mathrm{pH}$, arterial blood gases and vital signs data were recorded.

Results: In the post-anesthetic period, gastric $\mathrm{pH}$ was evaluated for $24 \mathrm{~h}$, samples were collected at onehour intervals. In addition, blood samples were collected for gastrin hormone evaluation before the anesthetic procedure (8-hour fast), during the anesthetic recovery period, and four months after the anesthetic procedure, 90 minutes after the morning meal. Gastric $\mathrm{pH}$ during the anesthetic period remained within physiological values (mean value $4.52 \pm 1.69$ ), without changes between times $(p>$ 0.05). After anesthesia, mean gastric $\mathrm{pH}$ values increased, remaining alkaline during the $24 \mathrm{~h}$ of

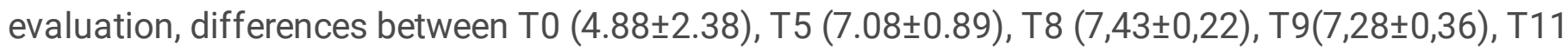
$(7.26 \pm 0.71), T 13(6.74 \pm 0.90)$, and T17 $(6.94 \pm 1.04)(p<0.05)$ were observed. There was an increase in gastrin hormone in the post-anesthetic period $(20.15 \pm 7.65 \mathrm{pg} / \mathrm{ml})$ compared to baseline $(15.15 \pm 3.82$ $\mathrm{pg} / \mathrm{ml})(\mathrm{p}<0.05)$.

Conclusions: The results obtained demonstrate that general inhalational anesthesia and dorsal decubitus in horses, for $90 \mathrm{~min}$, promotes gastric $\mathrm{pH}$ alkalinization for 24 hours after anesthesia, possibly induced by entero-gastric reflux. Therefore, gastric mucosa protectors should be considered preventively when horses are submitted to general anesthesia and supine.

\section{Background}

Equine gastric ulcer syndrome (EGUS) is considered a multifactorial syndrome, with prevalence between 53 to $93 \%$, is mainly caused by stress, prolonged fasting, diet, nutritional quality, sports activity, underlying diseases, drugs, among others [1]. Its occurrence is mainly in foals and athlete horses because those are submitted to constant stress, intense training, and controlled feeding [2]. Signs of EGUS range from mild to acute pain, with recurrent cramps, changes in attitude, decreased performance, constant salivation, bruxism, Anorexia, weight loss, and could result in the horse's death [1]. The diagnosis can be obtained through gastroscopy, when there is a suspicion of ulcerative esophagitis or gastric ulcer, as it is possible to assess the severity and quantity of lesions and, thus, make a classification of the condition [3]. The physiopathology of gastroesophageal reflux disease (GERD) and duodenogastric reflux disease observed in humans could be considered similar to the EGUS. These diseases are considered as chronic diseases that affect 10 to $30 \%$ of the population in North America (19.8\%), followed by Europe and the Middle East with $15.2 \%$ and $14.4 \%$, respectively, and East Asia with $5.2 \%$ [4]. It is caused by the reflux of acid from the stomach and bile fluid that combine and go over to the esophagus [6]. Most common 
clinical signs are regurgitation, dysphagia, dyspepsia, nausea, belching accompanied by acidity, epigastric pain, hoarseness, sleep disturbances, weight loss, amongst others [5]. risk factors described are intra-abdominal pressure such as (obesity, decubitus positioning, pregnancy), hiatal hernia, acid hypersecretion (Zollinger-Ellison Syndrome), esophageal dysfunction (post-myotomy), and late gastric emptying [3].

The diagnostic method for ERGE, and also for ERDG, is continuous $\mathrm{pH}$ measurement, which has excellent sensitivity (77-100\%) and specificity (88-100\%) [7]. For that, a pH meter is used, positioned in the lower esophagus, close to the cardia, which performs a continuous $\mathrm{pH}$ reading, monitoring it for 24 hours. This test is the most indicated to know how long the gastric juice remains in contact with the esophageal mucosa, measuring the $\mathrm{pH}$ peaks and relating them to the symptoms presented by the patient [8]. There is also the measurement of the serum concentration of gastrin, the most principal hormone in gastric physiology. That is mainly responsible for the increase in acid secretion in the stomach. Gastrin concentrations are routinely measured by radioimmunoassay, evaluating variations with prolonged fasting [9].

One of the medical recommendations for people with ERGE and ERDG is to tilt the bed $22^{\circ}$ to avoid reflux when lying down [10]. In the meantime, there are no reports, so far, in the consulted literature, that assess whether a horse once submitted to general inhalation anesthesia for surgical procedures, is subject to an increase in intra-abdominal pressure, especially when in the supine position, that reflects the occurrence of gastroesophageal and enterogastric reflux, and compromise the stomach and esophagus mucosa, and promote the triggering of gastric and esophageal ulcerations and EGUS [11, 12]. This study aims to evaluate changes in gastric $\mathrm{pH}$ and gastrin hormone in horses submitted to general inhalation anesthesia and supine to verify the possible occurrence of duodenogastric and gastroesophageal reflux.

\section{Materials And Methods}

\section{Animals}

Eight mares half-breed between 5 to 10 years and ranging from 300 to $500 \mathrm{~kg}$ were selected. The mares were fed coast cross hay and water ad libitum and commercial horse concentrate. the horses belonged to from the research facility clinical, surgery and rehabilitation research laboratory (LACCRE / ZMV). Horses were clinically healthy according to physical evaluation, being considered healthy based on clinical and laboratory tests.

\section{Ethical statement.}

The study was carried out at the Veterinary Hospital of the University of São Paulo, all procedures were conducted in accordance with the approved by the bioethics committee for the use of animals (CEUA), of the University of São Paulo - Faculty of Animal Science and Food Engineering under protocol $\mathrm{n}^{\circ}$ 1773270819. 


\section{Anesthetic protocol}

After an 8-hour fast, the mares were prepared in the containment trunk were a clinical examination, nasogastric probing, and a jugular vein trichotomy was performed. They were cannulated with a $14 \mathrm{G}$ catheter for drug administration. The anesthetic protocol was performed as follows: pre-anesthetic medication: detomidine (20 $\mathrm{\mu g} / \mathrm{kg}-1 \mathrm{IV})$, followed by methadone $(0.1 \mathrm{mg} / \mathrm{kg}-1 \mathrm{IV})$. Anesthetic induction: $10 \%$ ketamine $(2 \mathrm{mg} / \mathrm{kg}-1 \mathrm{IV})$ and midazolam $(0.1 \mathrm{mg} / \mathrm{kg}-1 \mathrm{IV})$ administered together. Maintenance phase: 90 min, using isoflurane diluted in $100 \%$ oxygen, in addition to controlled ventilation for maintain ETCO2 $(35-45 \mathrm{mmHg})$, ventilator pressure $(10 \mathrm{cmH} 20)$, and an inspiration/expiration fraction ratio 1:2. The oxygen volume was adjusted to $1 \mathrm{~L} / 100 \mathrm{~kg}$, isoflurane vaporization (1.5 MAC), and a positive endexpiratory PEEP pressure of $5 \mathrm{cmH} 2 \mathrm{O}$ was adjusted. Mean arterial pressure was maintained between 60$70 \mathrm{mmHg}$, using dobutamine infusion ( $5 \mu \mathrm{g} / \mathrm{kg}-1 \mathrm{IV})$.

\section{Serum gastrin protocol and assay}

Before anesthetic procedure, mares were removed from the pasture and led to a stable, where they fasted for $8 \mathrm{~h}$. After skin disinfection an 8-10 $\mathrm{ml}$ whole blood sample was collected by jugular venipuncture in clot activator tubes (BD, Vacutainer systems, Plymouth, UK), blood samples were kept at refrigeration temperature $4-8^{\circ} \mathrm{C}$ until processed in the laboratory. The blood samples were centrifuged during $15 \mathrm{~min}$ at $1,500 \mathrm{~g}$, serum was separated with a micropipette and then stored in $2 \mathrm{ml}$ tubes (Eppendorf) at $-3^{\circ} \mathrm{C}$ until analysis. Blood samples were collected at three moments, the first sample as mentioned above was to determine the basal gastrin concentration. The second one was obtained after 90 min of general anesthesia at the recovery room, after the mare was positioned in the lateral decubitus position. The last sample was performed fourth months after anesthesia, 90 min after the morning feeding without any prior fasting. Serum gastrin concentration was measured using a commercial available double antibody radioimmuno-assay designed for human use (Diagnostics Clinical Analysis, DAC, Pirassununga, SP).

\section{Gastric pH measurement}

\section{pH Calibration}

Calibration of the digital pH meter (Gehaka - PG1800) was performed using buffer three solutions, a neutral $(6-8 \mathrm{pH})$, acidic $(2-6 \mathrm{pH})$, and basic $(8-20 \mathrm{pH})$ fixed solution to obtain a calibration certificate specificity above $95 \%$. For $\mathrm{pH}$ measurement the $\mathrm{pH}$ meter requires the temperature assessment. In that order, a thermometer probe in the device was immersed into the gastric juice sample together with the $\mathrm{pH}$ meter electrode to obtain a precise $\mathrm{pH}$ value measurement.

\section{Gastric fluid collections and analysis}

A size 11 nasogastric tube with modified tip to avoid obstructions was passed through the nasal passages into the esophagus and stomach after the clinical examination. Then a thinner tube was inserted inside the nasogastric tube to collect gastric juice samples assisted by a $60 \mathrm{ml}$ syringe, the method consisted of aspirating with the syringe and then lowering the tube to led the sample descend by 
gravity. The first aliquot $(5 \mathrm{ml})$ of the gastric juice was discarded, and then the collection of $10 \mathrm{ml}$ of gastric content was performed, the sample was immediately analyzed to determine $\mathrm{pH}$. The transanesthetic period was divided into six samplings with intervals of $15 \mathrm{~min}$, until 90 min were completed (T15 - T90). Immediately after the recovery period (45 $\pm 1,86$ minutes), the sample collection and measurement began each hour ( $\mathrm{T} 1$ ) until $24 \mathrm{~h}$, during those $24 \mathrm{~h}$ the mare was placed into an individual stall where $1 \%$ of live weight concentrate was offered two times a day and coast cross hay and water were available ad libitum.

\section{Monitoring food and water intake}

After the anesthetic recovery time, mares were driven to an individual stable; and 30 min later food was offered. Mares were monitored for $24 \mathrm{~h}$, and an observer record the water and food intake, the interest in food or water, and the time that the animal spent feeding or drinking water.

\section{Statistical analysis}

Data was analyzed using a statistical software (Stata V.14.0, StataCorp. College Station, TX, US). A visual inspection of the data and the verification of normal distribution of variables using Shapiro-Wilk test was performed. To determine the difference between gastrin concentrations before and after anesthesia, paired samples Student's t-test or Wilcoxon test (according to data distribution) were performed using as a reference value the gastrin obtained at TO. ANOVA or Kruskal Wallis tests and their post-hoc tests were made to determine if there were differences between groups defined by time (T0, T30, T60, T75, and T90) over each variable included in the study (gastric $\mathrm{pH}$, arterial $\mathrm{pH}, \mathrm{PCo} 2$ and PO2). In addition, the same test was used to o determine if there was any relation between the gastric $\mathrm{pH}$ and the food and water consumption. The statistical significance of the all analyzes was considered as $95 \%$, with an $a=0.05$.

\section{Results}

In this study, the nasogastric tube was constantly repositioned due to its length, and marks were made in the tube to preserve the collection points, although, minimal adjustments were done during the collection process. Seven mares tolerated nasogastric tubes without difficulties during all the process, at night and during feeding hours. However, one mare's tube had to be withdrawn about 11 hours after start of the trial due to evident gastric discomfort and pain.

\section{Gastric pH}

During anesthesia, the $\mathrm{pH}$ remained within physiological ranges (mean value $4.52 \pm 1.69$ ). There was no changes in $\mathrm{pH}$ during the time of general anesthesia, and no correlation was observed between the time of anesthesia and gastric $\mathrm{pH}(\mathrm{p}=0.05)$ The $\mathrm{pH}$ value of the samples obtained during anesthesia are shown in (Fig. 1).

Gastric pH averages during post-anesthesia, samples collected at one-hour intervals for 24 hours (Fig. 2). Average recorded alkaline gastric $\mathrm{pH}$ values above the physiological value for the species throughout the 
24 hours. Mean values above the physiological values for the species were observed, with significant differences throughout the 24 h post-anesthesia in T5, T8, T9, T11, T13, T17 relevant to T0 $(p<0.05)$.

The mean $\mathrm{pH}$ values when mares consumed concentrate was $6.26 \pm 1.28$, hay $6.71 \pm 1.38$, or water $6.58 \pm 1.17$ during the $24 \mathrm{~h}$ of the post-anesthetic. Analyses show that water and hay did not interfere with the $\mathrm{pH}$ values, while concentrate presented lower $\mathrm{pH}$ values after its consumption. These findings could suggest that water and food consumption is not responsible for the alkalinization of gastric $\mathrm{pH}$ observed (Table 1).

\section{Serum Gastrin measuring}

Serum gastrin concentrations in mares during evaluated at fast time, post-anesthesia, and at 90 min after feeding, showed differences between the values at basal time post-anesthetic period $(p<0.03)$, while no differences were observed between feed and post-anesthesia or fasted times $(p>0.05)$ (Fig. 3).

\section{Discussion}

It is currently known that the monitoring of intragastric $\mathrm{pH}$ in human medicine is commonly used in hospital routine as a "gold-standard" tool for detecting changes in gastric physiology, diagnosis of gastrointestinal diseases such as gastroesophageal reflux (GERD), gastritis and disease by duodenogastric reflux $[5,10]$. In equine medicine, research on the physiological intragastric environment involves studies in nutrition, pharmacology, and sports medicine $[3,9,13-16]$, but studies involving general inhalational anesthesia while positioned at dorsal decubitus are unknown. This study is the first to report post-anesthetic gastric alkalinization in horses over a $24 \mathrm{~h}$ period.

Gastroesophageal reflux is a well-documented syndrome in human medicine $[17,18]$. In veterinary medicine, there are studies in small animal medicine reporting episodes of esophagitis, and esophageal stenosis, due to the action of different drugs used in anesthesia, which have a relaxing effect on the lower esophageal sphincter [19]. Cholinergic activation and anesthesia-induced vagal stimulation increases hydrochloric acid production and contributes to reported esophageal adverse effects [20,21]. On the other hand, it was not verified in the consulted literature, the correlation of the anesthetic procedure and supine position in horses with the triggering or exacerbation of esophagitis, gastritis, or gastric ulcers.

General anesthesia and decubitus in horses are known to increase intra-abdominal pressure [22-24]. Lorenzo, Figueras \& Merritt (2002)[14] demonstrated that the increase in intra-abdominal pressure in horses can overcome the pressure of the lower esophageal sphincter, obeying Pascal's law, resulting in episodes of gastroesophageal reflux $[25,26]$. Additionally, anesthetic drugs such as alpha-2 agonists, including detomidine, benzodiazepines, including midazolam, as well as inhaled anesthetics, such as isoflurane, promote relaxation of the esophageal smooth muscle, contributing to the occurrence of reflux of gastric contents into the esophagus in the transanesthetic period $[27,28]$. It is noteworthy that, in this study, the $\mathrm{pH}$ of the esophageal content at the time of reflux was not evaluated, in order to detect the presence only of gastric acid or, also, the presence of bile salts, if the reflux occurred together 
duodenogastric. However, as there was no change in gastric $\mathrm{pH}$ in the trans-anesthetic period, it is assumed that duodenogastric reflux did not pass in this period.

The mean value of basal gastric $\mathrm{pH}$, obtained after $8 \mathrm{~h}$ of fasting, reflected importance within the limit considered physiological for the species $[20,21,29]$ and the mean values did not change over the 90 mins of general inhalational anesthesia and supine. On the other hand, after anesthetic recovery, alkalinization of gastric contents was observed, which could be explained by the presence of enterogastric reflux due to changes in post-anesthetic gastrointestinal motility $[15,21,30]$. In this case, the presence of bile salts would be responsible for the alkaline $\mathrm{pH}$ observed in post-anesthetic evaluations. Although not performed in this study, the resulting analysis of gastric juice with pHmetry would be interesting to demonstrate the presence and concentration of bile salts, diagnosing duodenogastric reflux [31-33].

It is reported that a disorder of gastric and duodenal motility results in an alkaline content in the stomach, generating mixed reflux (alkaline and acid) and greater exposure of the gastric mucosa to bile salts [3436]. Changes in intestinal motility in the post-anesthetic period may have a direct relationship with the anesthetic protocol used. One of the side effects of detomidine is hypomotility, caused by presynaptic inhibition of a2 receptors, reducing the release of noradrenaline and acetylcholine in the enteric plexus [21]. The isoflurane used in this study during general inhalation anesthesia may also be responsible for a reduction in postoperative gastrointestinal motility, as demonstrated in dogs after prolonged inhalation anesthesia with sevoflurane, where there was a reduction in gastric and small bowel motility, with the gradual return after 12 to 15 hours of the anesthetic procedure, while the time of gastric emptying extended up to a period between 30 and 40 hours [37].

Furthermore, it was found that post-anesthetic water and hay consumption did not change gastric $\mathrm{pH}$, and concentrate consumption promoted acidification, which is physiological, due to the change in saliva production [38]. Thus, the continuous alkalinization of gastric $\mathrm{pH}$ observed in the 24 hours post-anesthetic cannot be correlated with food and water intake, which is possibly related to a post-anesthetic dysmotility promoted by the anesthetic procedure.

The assessment of the concentration of the gastrin hormone has been used in the clinical routine of horses for the diagnosis of gastric alterations and affections since this hormone provides information on the increase in gastric stimulation and on the increase in the production of acid in the stomach. In this study, there was no difference in the serum gastrin concentration about fasting or feeding the horses, with values ranging from $15.15 \pm 3.82 \mathrm{pg} / \mathrm{ml}$ when fasting and $19.28 \pm 6.26 \mathrm{pg} / \mathrm{ml}$ after feeding. These values are similar to those reported in the literature for the equine species, which range from less than $8 \mathrm{pg} / \mathrm{ml}$ to $17.5 \mathrm{pg} / \mathrm{ml}$ during fasting [39-42]. However, after the procedure of general inhalation anesthesia and supine position, an increase in mean gastrin values $(20.15 \pm 7.65 \mathrm{pg} / \mathrm{ml})$ was observed. This elevation can be explained by the fact that, during general inhalational anesthesia, there is an increase in pressure in the abdominal cavity generated by the supine position, exerting pressure on the stomach, which results in stimulation of gastric mucosa $\mathrm{G}$ cells to production of gastrin [43]. In addition, 
the gastrin elevation observed in the immediate post-anesthetic moment may be due to the inhibition of histamine and the acid response induced by gastrin, possibly correlated with the suppressive effects of anesthetic drugs on parietal cells and enterochromaffin cells, increasing serum gastrin, but without sufficient action to balance the acidity of gastric $\mathrm{pH}$ after anesthesia [44-46].

It's known that the presence of gastroesophageal reflux or gastric duodenum can be considered physiological when transiently. However, when time is prolonged, this event is considered, pathological as observed in this study during 24 hours $[21,34,43,47]$. Duodenal contents, specifically bile salts, can have a more corrosive effect when mixed with acid in the gastric mucosa, are considered the primary cause of alkaline gastritis. It's observed that duodenogastric reflux, in people, brings a significant number of lesions in the upper gastrointestinal tract, esophagitis, erythema, abdominal pain, gastric mucosal hyperplasia, represented by histological changes of this mucosa [35,36], in addition to changes in the number of gastrin, somatostatin, and serotonin cells, which can result in chronic atrophic gastritis and intestinal metaplasia $[34,48,49]$. In adult horses, duodenogastric reflux has been shown to alter electrolyte transport and induce the formation of erosions and ulcers in the stratified squamous gastric mucosa, suggesting pathophysiological mechanisms similar to duodenogastric reflux disease in humans[47].

Equine gastric ulcer syndrome (EGUS) is commonly seen in the majority of the $80 \%-90 \%$ horse population[50-54], but underdiagnosed and often undiagnosed, generating important losses, both in sports performance and in economic losses from treatments. According to the $\mathrm{pH}$ assessments in this study, there is alkalinization of the gastric $\mathrm{pH}$ for 24 hours after general inhalational anesthesia and decubitus in horses, it's relevant to consider the use of drugs that promote the protection of the gastric mucosa in a preventive manner. $[55,56]$.

The use of drugs that protect the gastric mucosa, such as sucralfate, which binds to positively charged proteins, forming a gel that adheres to the gastric mucosa, providing uniform protection against acid attack, pepsin and bile salts. It presents interesting results in the mechanism of pepsin inhibition and has bile salt chelating action, improving the increase in fibroblast growth factors and inducing an increase in prostaglandins in the mucosa, promoting the healing of gastric ulcers $[10,57,58]$. Also, alginates, being a composition of sodium alginate, sodium bicarbonate, and calcium carbonate, form, when in contact with gastric acid, an alginic acid gel film, with almost neutral $\mathrm{pH}$, protective in the stomach and esophagus, reducing the symptoms of gastroesophageal reflux, and enterogastric [59]. Another therapeutic option in the first 24hours after the anesthetic procedure would be the use of prokinetic drugs that stimulate duodenal peristalsis, thus avoiding the presence of mixed content (bile salts and hydrochloric acid) in the stomach, favoring the inflammatory condition of the gastric mucosa [60-62]. Also, the association of acupuncture as an integrative treatment may have favorable results, related to increased motilin, wave stimulation of the migrating myoelectric complex and acceleration of time for gastric emptying $[63,64]$.

A limitation for this study was the absence of a gastroscope to carry out a continuous evaluation of the stomach and esophagus to observe in real time the periods of reflux. Moreover, the concomitant 
evaluation of gastric juice with $\mathrm{pH}$ measurement was not carried out to demonstrate the presence of salts in the bile ducts, diagnosing duodenogastric reflux.

\section{Conclusions}

General inhalation anesthesia and supine position do not change gastric $\mathrm{pH}$ in the trans-anesthetic period but result in increased serum gastrin in the immediate post-anesthetic period and the post-anesthetic alkalinization of gastric $\mathrm{pH}$ for $24 \mathrm{~h}$.

\section{Declarations}

\section{Ethics approval and consent to participate.}

All methods were approved and performed in accordance with the relevant guidelines and regulations of the University of São Paulo's Animal Care and Use Committee, under protocol number 1773270819. The authors obtained written informed consent to use the animals in their study from the laboratory owner of the animals (LACCRE/ZMV).

\section{Consent for publication.}

Not applicable.

\section{Availability of data and materials.}

The datasets generated and/or analysed during the current study are available in the repository, https://teses.usp.br/index.php?option=com_jumi\&fileid=11\&ltemid=76\&lang=es.

Name: Suarez Guerrero Jesus Leonardo. The dataset used/or analysed during the current study are available from 04/02/2022

\section{Competing interests.}

No competing interests have been declared.

\section{Funding}

The authors thank São Paulo Research Foundation (FAPESP), grant 2020/09633-0 for financial support. They contributed to collection and analysis, and in writing the manuscript.

\section{Acknowledgements.}

The authors would like to express gratitude to University of São Paulo, FAPESP for the financial suport.

\section{References}


1. Andrews FM, NADEAU JA. Clinical syndromes of gastric ulceration in foals and mature horses. Equine Vet J 1999;31:30-3.

2. Nieto JE, Snyder JR, Beldomenico P, Aleman M, Kerr JW, Spier SJ. Prevalence of gastric ulcers in endurance horses - A preliminary report. Vet J 2004;167:33-7. https://doi.org/10.1016/j.tvjl.2003.09.005.

3. Baker SJ, Johnson PJ, David A, Cook CR. Idiopathic gastroesophageal reflux disease in an adult horse. J Am Vet Med Assoc 2004;224:1967-1970+1931. https://doi.org/10.2460/javma.2004.224.1967.

4. Rubenstein JH, Chen JW. Epidemiology of Gastroesophageal Reflux Disease. Gastroenterol Clin 2014;43:1-14. https://doi.org/10.1016/j.gtc.2013.11.006.

5. Rodrigo Octavio Rojas Díaz,* Julio Alberto Pérez Sosa *, **, Rafael Contreras Ruiz Velasco*. Reflujo duodenogástrico. Definición y diagnóstico. Cir Gen 2015;37:3-4.

6. Nieto J. Gastrointestinal diseases of athletic horses. Second Edi. Elsevier Ltd; 2013. https://doi.org/10.1016/B978-0-7020-4771-8.00047-8.

7. Hani AC, Galindo A, Leguizamo A, Maldonado C, Páramo D, Costa V, et al. Guía de práctica clínica para la enfermedad por reflujo gastroesofágico. Rev Colomb Gastroenterol 2015;30:1-8.

8. Andersen J, Naesdal J, Ström M. Identical 24-hour gastric ph profiles when using intragastric antimony or glass electrodes or aspirated gastric juice. Scand J Gastroenterol 1988;23:375-9. https://doi.org/10.3109/00365528809093882.

9. Baker SJ, Gerring EL, Fox MT. Twenty-four hour gastric $\mathrm{pH}$ monitoring and blood gastrin concentrations in fasted ponies. Res Vet Sci 1993;55:261-4. https://doi.org/10.1016/00345288(93)90091-S.

10. Suárez Parga J.M, Erdozaín Sosa J.C, Comas Redondo C VPR. Enfermedad por Reflujo Gastroesofágico: Tratamiento. Prensa Med Argent 1999;23:97-103.

11. Brosnahan MM, Holbrook TC, Gilliam LL, Ritchey JW, Confer AW. Intra-abdominal hypertension in two adult horses: Case Series. J Vet Emerg Crit Care 2009;19:174-80. https://doi.org/10.1111/j.14764431.2009.00400.x.

12. Costa Farré C. Hipoxemia intra-operatoria en caballos anestesiados con isoflurano y ventilados a presión positiva intermitente incidencia, prevención e implicaciones post-operatorias en caballos operados de cólico 2011.

13. Andrews FM, Jenkins CC, Frazier D, Blackford JT. Gastric secretion in foals: measurement by nasogastric intubation with constant infusion and aspiration. Equine Vet J 1992;24:75-9. https://doi.org/https://doi.org/10.1111/j.2042-3306.1992.tb04792.x.

14. Lorenzo-Figueras $\mathrm{M}$, Merritt $\mathrm{AM}$. Effects of exercise on gastric volume and $\mathrm{pH}$ in the proximal portion of the stomach of horses. Am J Vet Res 2002;63:1481-7. https://doi.org/10.2460/ajvr.2002.63.1481.

15. MURRAY MJ, SCHUSSER GF. Measurement of 24-h gastric $\mathrm{pH}$ using an indwelling $\mathrm{pH}$ electrode in horses unfed, fed and treated with ranitidine. Equine Vet J 1993;25:417-21. 
https://doi.org/10.1111/j.2042-3306.1993.tb02983.x.

16. Pereira MC, Levy FL, Valadão CAA, Ferraz GC, Queiroz-Neto A. Preliminary Study of the Gastric Acidity in Thoroughbred Horses at Rest after Enteral Administration of Esomeprazole Magnesium (Nexium). J Equine Vet Sci 2009;29:791-4. https://doi.org/10.1016/j.jevs.2009.10.006.

17. Huerta-Iga F, Bielsa-Fernández M V, Remes-Troche JM, Valdovinos-Díaz MA, Tamayo-de la Cuesta JL. Diagnosis and treatment of gastroesophageal reflux disease: recommendations of the Asociación Mexicana de Gastroenterología. Rev Gastroenterol Mex 2016;81:208-22. https://doi.org/10.1016/j.rgmx.2016.04.003.

18. Olmos JA, Piskorz MM, Vela MF. [Gastroesophageal Reflux Disease Review (GERD)]. Acta Gastroenterol Latinoam 2016;46:160-72.

19. Garcia RS, Belafsky PC, Della Maggiore A, Osborn JM, Pypendop BH, Pierce T, et al. Prevalence of Gastroesophageal Reflux in Cats During Anesthesia and Effect of Omeprazole on Gastric pH. J Vet Intern Med 2017;31:734-42. https://doi.org/10.1111/jvim.14704.

20. Sandin A, Andrews FM, Nadeau JA, Nilsson G. Effect of nervous excitation on acid secretion in horses. Acta Physiol Scand 2000;168:437-42. https://doi.org/10.1046/j.1365-201X.2000.00682.x.

21. Sutton DGM, Preston T, Christley RM, Cohen ND, Love S, Roussel AJ. The effects of xylazine, detomidine, acepromazine and butorphanol on equine solid phase gastric emptying rate. Equine Vet J 2002;34:486-92. https://doi.org/10.2746/042516402776117818.

22. Schauvliege S, Binetti A, Duchateau L, van Dijk JJ, Gasthuys F. Cardiorespiratory effects of a $7^{\circ}$ reverse Trendelenburg position in anaesthetized horses: a randomized clinical trial. Vet Anaesth Analg 2018;45:648-57. https://doi.org/https://doi.org/10.1016/j.vaa.2018.03.011.

23. Salciccia A, Gougnard A, Grulke S, de la Rebière de Pouyade G, Libertiaux V, Busoni V, et al. Gastrointestinal effects of general anaesthesia in horses undergoing non abdominal surgery: focus on the clinical parameters and ultrasonographic images. Res Vet Sci 2019;124:123-8. https://doi.org/https://doi.org/10.1016/j.rvsc.2019.03.011.

24. de Paula VB, Canola PA, Rivera GG, Bonacin YS, Del Rio LA, Canola JC, et al. Intra-abdominal Pressure Screening of Horses With Colic. J Equine Vet Sci 2020;90:102998. https://doi.org/https://doi.org/10.1016/j.jevs.2020.102998.

25. Wernly JA, DeMeester TR, Bryant GH, Wang Cl, Smith RB, Skinner DB. Intra-abdominal pressure and manometric data of the distal esophageal sphincter. Their relationship to gastroesophageal reflux. Arch Surg 1980;115:534-9. https://doi.org/10.1001/archsurg.1980.01380040156028.

26. Durongphongtorn S, McDonell WN, Kerr CL, Neto FJT, Mirakhur KK. Comparison of hemodynamic, clinicopathologic, and gastrointestinal motility effects and recovery characteristics of anesthesia with isoflurane and halothane in horses undergoing arthroscopic surgery. Am J Vet Res 2006;67:3242. https://doi.org/10.2460/ajvr.67.1.32.

27. Muir WW. Chapter 10 - Anxiolytics, Nonopioid Sedative-Analgesics, and Opioid Analgesics. In: Muir WW, Hubbell JAE, editors. Equine Anesth. (Second Ed. Second Edi, Saint Louis: W.B. Saunders; 2009, p. 185-209. https://doi.org/https://doi.org/10.1016/B978-1-4160-2326-5.00010-9. 
28. Lambertini C, Pietra M, Galiazzo G, Torresan F, Pinna S, Pisoni L, et al. Incidence of Gastroesophageal Reflux in Dogs Undergoing Orthopaedic Surgery or Endoscopic Evaluation of the Upper Gastrointestinal Tract. Vet Sci 2020;7:144. https://doi.org/https://doi.org/10.3390/vetsci7040144.

29. Kitchen DL, Burrow JA, Heartless CS, Merritt AM. Effect of pyloric blockade and infusion of histamine or pentagastrin on gastric secretion in horses. Am J Vet Res 2000;61:1133-9. https://doi.org/10.2460/ajvr.2000.61.1133.

30. Mitchell CF, Malone ED, Sage AM, Niksich K. Evaluation of gastrointestinal activity patterns in healthy horses using B mode and Doppler ultrasonography. Can Vet J 2005;46:134.

31. Fuchs KH, DeMeester TR, Hinder RA, Stein HJ, Barlow AP, Gupta NC. Computerized identification of pathologic duodenogastric reflux using 24-hour gastric pH monitoring. Ann Surg 1991;213:13-20. https://doi.org/10.1097/00000658-199101000-00003.

32. Mercan E, Duman U, Tihan D, Dilektasli E, Senol K. Cholecystectomy and duodenogastric reflux: interacting effects over the gastric mucosa. Springerplus 2016;5:1970. https://doi.org/10.1186/s40064-016-3641-z.

33. Agin M, Kayar Y. The Effect of Primary Duodenogastric Bile Reflux on the Presence and Density of Helicobacter pylori and on Gastritis in Childhood. Medicina (Kaunas) 2019;55. https://doi.org/10.3390/medicina55120775.

34. Mabrut JY, Collard JM, Baulieux J. [Duodenogastric and gastroesophageal bile reflux]. J Chir (Paris) 2006;143:355-65. https://doi.org/10.1016/s0021-7697(06)73717-6.

35. Chen T-F, Yadav PK, Wu R-J, Yu W-H, Liu C-Q, Lin H, et al. Comparative evaluation of intragastric bile acids and hepatobiliary scintigraphy in the diagnosis of duodenogastric reflux. World J Gastroenterol 2013;19:2187-96. https://doi.org/10.3748/wjg.v19.i14.2187.

36. McCabe ME, Dilly CK. New Causes for the Old Problem of Bile Reflux Gastritis. Clin Gastroenterol Hepatol 2018;16:1389-92. https://doi.org/https://doi.org/10.1016/j.cgh.2018.02.034.

37. Boscan P, Cochran S, Monnet E, Webb C, Twedt D. Effect of prolonged general anesthesia with sevoflurane and laparoscopic surgery on gastric and small bowel propulsive motility and $\mathrm{pH}$ in dogs. Vet Anaesth Analg 2014;41:73-81. https://doi.org/https://doi.org/10.1111/vaa.12093.

38. Damkel C, Snyder A, Uhlig A, Coenen M, Schusser GF. Impact of diet on 24-hour intragastric pH profile in healthy horses. Berl Munch Tierarztl Wochenschr 2015;128:345-9.

39. Young DW, Smyth GB. Validation of a radioimmunoassay for measurement of gastrin in equine serum. Am J Vet Res 1988;49:1179-1183.

40. Smyth GB, Young DW, Hammond LS. Effects of diet and feeding on postprandial serum gastrin and insulin concentration in adult horses. Equine Vet J Suppl 1989:56-9. https://doi.org/10.1111/j.20423306.1989.tb05657.x.

41. Young DW, Smyth GB. Molecular forms of gastrin in antral mucosa of the horse. Domest Anim Endocrinol 1990;7:55-62. https://doi.org/https://doi.org/10.1016/0739-7240(90)90054-4.

42. Wickens CL, McCall CA, Bursian S, Hanson R, Heleski CR, Liesman JS, et al. Assessment of Gastric Ulceration and Gastrin Response in Horses with History of Crib-Biting. J Equine Vet Sci 2013;33:739- 
45. https://doi.org/10.1016/j.jevs.2012.12.004.

43. Campbell-Thompson ML, Merritt AM. Basal and pentagastrin-stimulated gastric secretion in young horses. Am J Physiol - Regul Integr Comp Physiol 1990;259.

https://doi.org/10.1152/ajpregu.1990.259.6.r1259.

44. Norlén P, Kitano M, Lindström E, Håkanson R. Anaesthetic agents inhibit gastrin-stimulated but not basal histamine release from rat stomach ECL cells. Br J Pharmacol 2000;130:725-30. https://doi.org/10.1038/sj.bjp.0703347.

45. Norlén $P$, Ericsson $P$, Kitano $M$, Ekelund $M$, Håkanson R. The vagus regulates histamine mobilization from rat stomach ECL cells by controlling their sensitivity to gastrin. J Physiol 2005;564:895-905. https://doi.org/10.1113/jphysiol.2005.082677.

46. Fykse V, Solligård E, Bendheim MØ, Chen D, Grønbech JE, Sandvik AK, et al. ECL cell histamine mobilization and parietal cell stimulation in the rat stomach studied by microdialysis and electron microscopy. Acta Physiol (Oxf) 2006;186:37-43. https://doi.org/10.1111/j.1748-1716.2005.01504.x.

47. Berschneider HM, Blikslager AT, Roberts MC. Role of duodenal reflux in nonglandular gastric ulcer disease of the mature horse. Equine Vet J Suppl 1999:24-9. https://doi.org/10.1111/j.20423306.1999.tb05164.x.

48. Tzaneva M. Effects of duodenogastric reflux on gastrin cells, somatostatin cells and serotonin cells in human antral gastric mucosa. Pathol - Res Pract 2004;200:431-8. https://doi.org/https://doi.org/10.1016/j.prp.2004.04.002.

49. Beltrán MA. Pancreaticobiliary reflux in patients with a normal pancreaticobiliary junction: Pathologic implications. World J Gastroenterol 2011;17:953-62. https://doi.org/10.3748/wjg.v17.i8.953.

50. Murray MJ. Equine model of inducing ulceration in alimentary squamous epithelial mucosa. Dig Dis Sci 1994;39:2530-5. https://doi.org/10.1007/BF02087686.

51. Buchanan BR, Andrews FM. Treatment and prevention of equine gastric ulcer syndrome. Vet Clin Equine Pract 2003;19:575-97.

52. Videla R, Andrews FM. New Perspectives in Equine Gastric Ulcer Syndrome. Vet Clin North Am Equine Pract 2009;25:283-301. https://doi.org/10.1016/j.cveq.2009.04.013.

53. Álvarez AJC, Álvarez PJ, Castaño BL. Conceptos generales sobre ulceración gástrica de los caballos. Parte 1. Rev Colomb Cienc Anim 2012;4:233-66.

54. Cardona J, Alvarez J, Castaño L. Conceptos Generales Sobre Ulceración Gastrica De Los Caballos. Parte 2. Diagnóstico Y Tratamiento. Rev Colomb Cienc Anim - RECIA 2013;5:194. https://doi.org/10.24188/recia.v5.n1.2013.484.

55. Dart AJ, Peauroi JR, Hodgson DR, Pascoe JR. Efficacy of metoclopramide for treatment of ileus in horses following small intestinal surgery: 70 cases (1989-1992). Aust Vet J 1996;74:280-4. https://doi.org/10.1111/j.1751-0813.1996.tb13775.x.

56. Okamura K, Sasaki N, Yamada M, Yamada H, Inokuma H. Effects of mosapride citrate, metoclopramide hydrochloride, lidocaine hydrochloride, and cisapride citrate on equine gastric 
emptying, small intestinal and caecal motility. Res Vet Sci 2009;86:302-8.

https://doi.org/https://doi.org/10.1016/j.rvsc.2008.07.008.

57. Surdea-Blaga T, Băncilă I, Dobru D, Drug V, Frățilă O, Goldiș A, et al. Mucosal Protective Compounds in the Treatment of Gastroesophageal Reflux Disease. A Position Paper Based on Evidence of the Romanian Society of Neurogastroenterology. J Gastrointestin Liver Dis 2016;25:537-46. https://doi.org/10.15403/jgld.2014.1121.254.dea.

58. Kroch DA, Madanick RD. Medical Treatment of Gastroesophageal Reflux Disease. World J Surg 2017;41:1678-84. https://doi.org/10.1007/s00268-017-3954-2.

59. Nieto JE, Morales B, Yamout SZ, Stanley SD, Harmon FA, Snyder JR. In vivo and in vitro effects of neostigmine on gastrointestinal tract motility of horses. Am J Vet Res 2013;74:579-88.

60. Szarszewski A, Korzon M, Kamiñska B, Lass P. Duodenogastric reflux: clinical and therapeutic aspects. Arch Dis Child 1999;81:16-20. https://doi.org/10.1136/adc.81.1.16.

61. Pueyo JS. Update on gastroesophageal reflux disease. Gastroenterol Hepatol 2014;37:73-82.

62. Monteiro RLR, Kobayasi MAMR, Araujo MR de, Monteiro DR, Andreollo NA. Omeprazole and adenocarcinoma in the stomach of rats submitted to duodenogastric reflux. Is there a protective effect? Acta Cir Bras 2020;35:e202000904-e202000904. https://doi.org/10.1590/s0102865020200090000004.

63. Zhang C, Qin Y, Guo B. Clinical study on the treatment of gastroesophageal reflux by acupuncture. Chin J Integr Med 2010;16:298-303. https://doi.org/10.1007/s11655-010-0516-y.

64. Reginato GM. Efeito da eletroacupuntura sobre a motilidade e trânsito intestinal de equinos 2019. https://doi.org/10.11606/D.74.2020.tde-27012020-113228.

\section{Tables}

Due to technical limitations, table 1 is only available as a download in the Supplemental Files section.

\section{Figures}




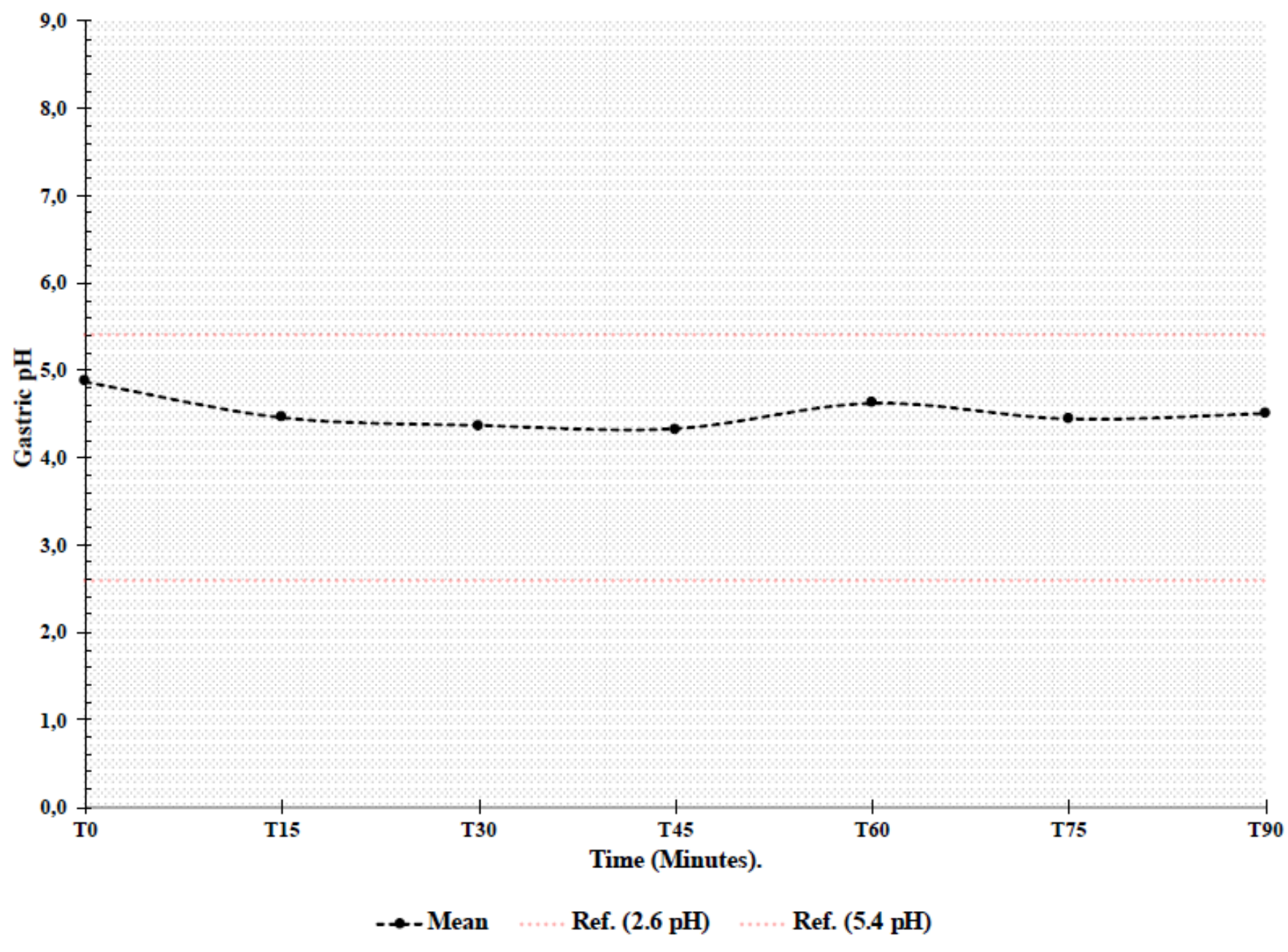

Figure 1

Average gastric $\mathrm{pH}(--)$ during of anesthesia (90 min) of eight mares. T: time of sampling in minutes. Red lines represent physiological values. 


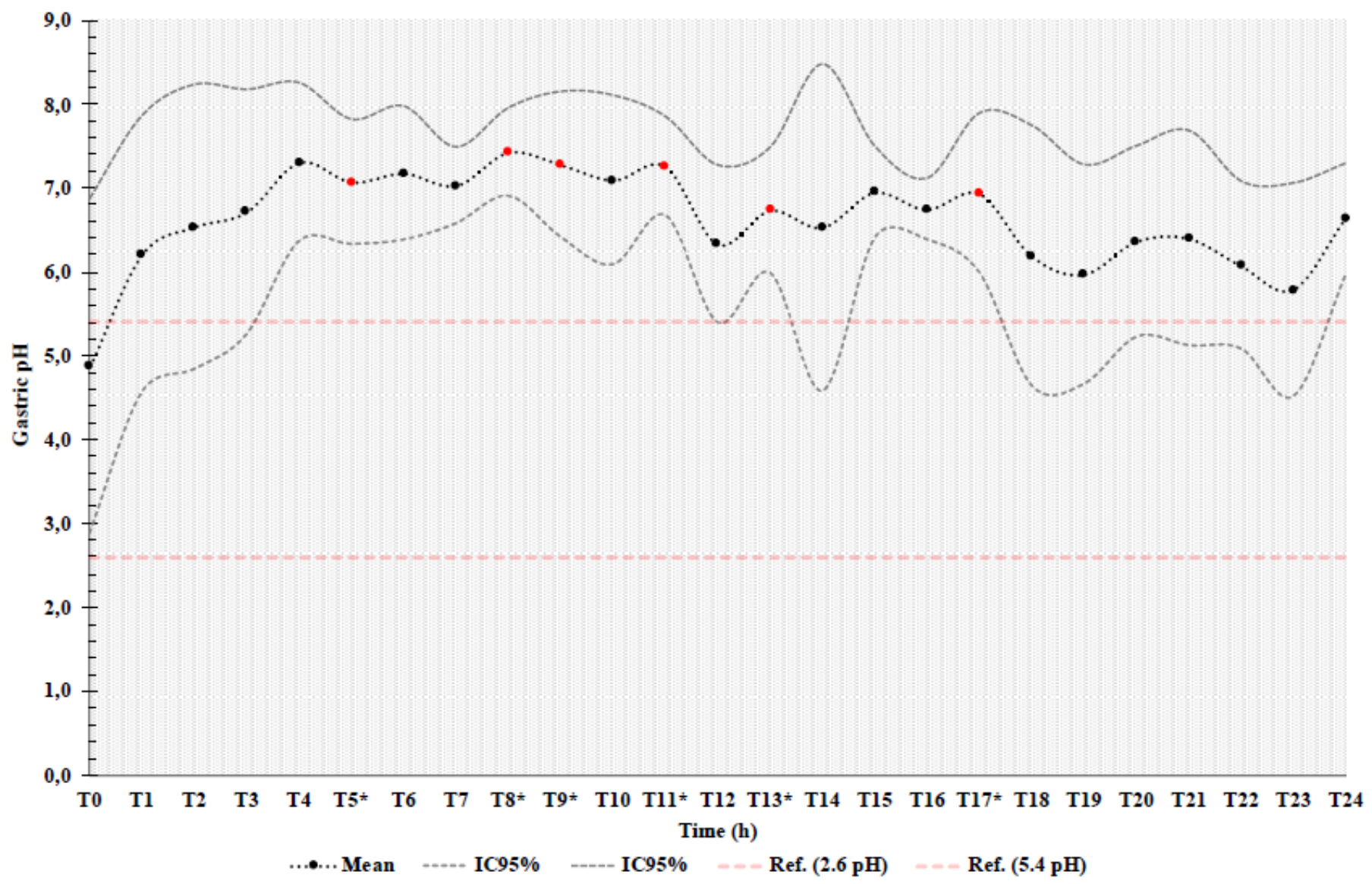

Figure 2

Gastric $\mathrm{pH}$ profiles after general anesthesia for $24 \mathrm{~h}$ with free access to water, hay, and feed. T: time of sampling in hours. - - statistical difference between times $(p=<0.05)$. Gray line represents the $95 \%$ confidence interval limits. 


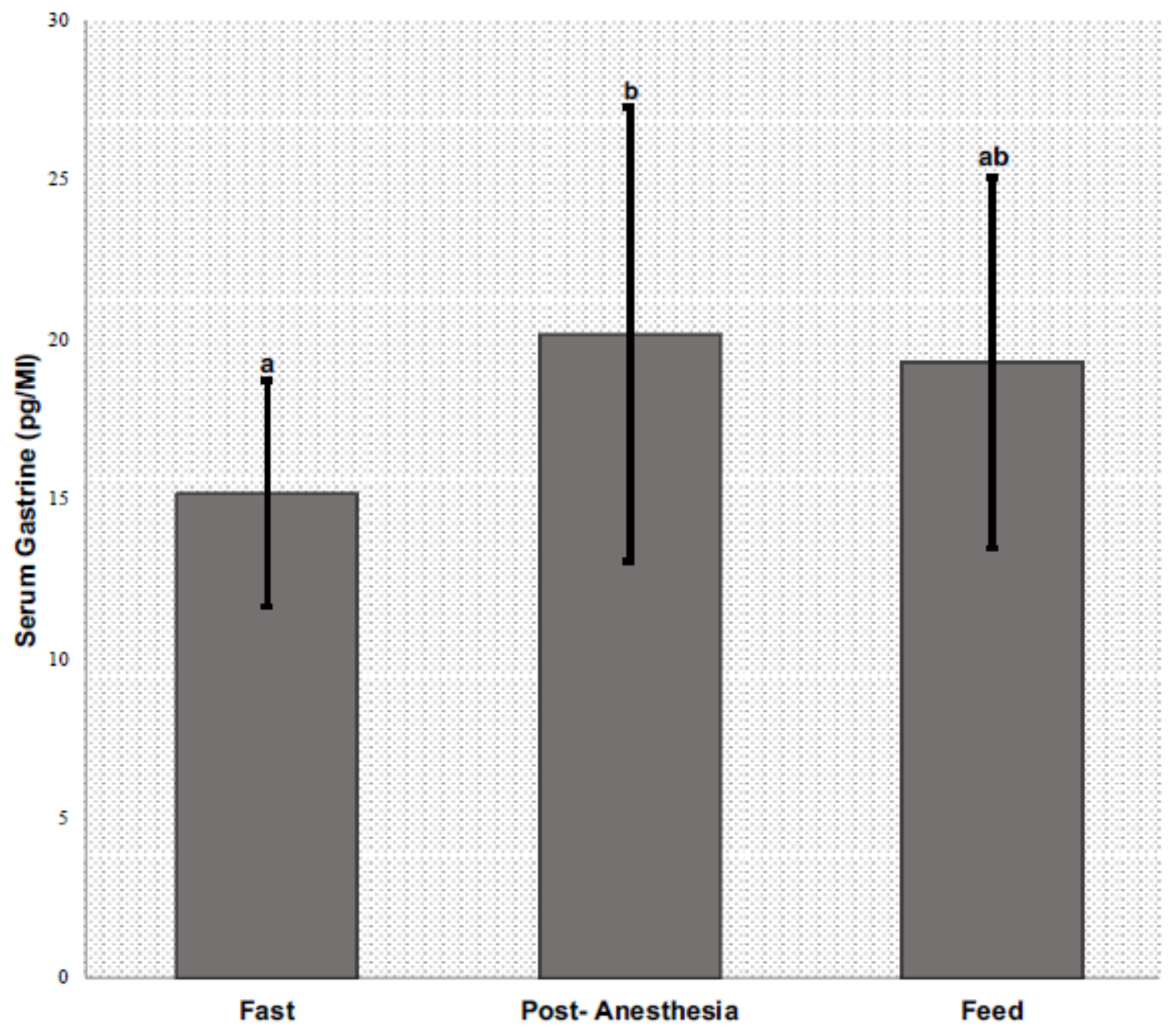

Figure 3

Mean serum gastrin concentrations in fasting, post-anesthesia, and 90 min after feeding. Superscripts with uncommon letters differ from each other with a significance level $(p<0.03)$.

\section{Supplementary Files}

This is a list of supplementary files associated with this preprint. Click to download.

- Table1.pdf 